11 Anagnostides AA, Chadwick VS, Fitzpatrick ML, Maton PN. A cephalic phase of biliary secretion. Clin Sci 1983; 65: 1-12

\section{Acetorphan and diarrhoea}

EDITOR, - We were interested to read the paper of Baumer (Gut 1992; 33: 753-8) regarding the antisecretory effects of enkephalinase (neutral endopeptidase 24.11) inhibition with acetorphan in cathartic and infectious diarrhoea in man and would like to stress another role for enkephalinase enzymes in down regulating the inflammatory response.

Enkephalinase (neutral endopeptidase 24.11 ) reduces the response of neutrophils to inflammatory peptide stimuli ${ }^{2}$ including the bacterially derived F-met peptides. Peptidase enzymes are thought to protect the gut from the inflammation induced by bacterial peptides. "We have studied enkephalinase activity in peripheral blood neutrophils in ulcerative colitis ${ }^{4}$ : patients with ulcerative colitis showed enkephalinase activity of $1.07 \times 10^{-6} \mathrm{M} / 30$ $\mathrm{min} / 10^{\varsigma}$ neutrophils (geometric mean); in contrast healthy volunteers showed enkephalinase activity of $2 \cdot 24$ (difference from colitis patients $p=0.048$, confidence interval for ratio of means 0.23 to 0.98 ). These preliminary data suggest that peripheral blood neutrophils from patients with active ulcerative colitis may have a reduced ability to down regulate their responses to both bacterial F-met peptides and endogenous neuropeptides although it is not clear whether this is primary or secondary.

$$
\begin{array}{r}
\text { A T COLE } \\
\text { C J HAWKEY } \\
\text { Department of Medicine, } \\
\text { University Hospital, } \\
\text { Queen's Medical Centre, } \\
\text { Nottingham } \\
\text { NG7 2UH }
\end{array}
$$

1 Nadel JA. Decreased neutral endopeptidases: possible role in inflammatory diseases of airways. Lung 1990; 168: 123-7.

2 Shipp MA, Stefano GB, D'Adamio L, Switzer SN et al. Down regulation of enkephalin-mediated (a) inflammatory responses by CD10/neutral
peptidase 24.11. Nature 1990; 347: 394-6.

3 Chadwick VS, Schlup MMI, Cooper BT, Broom MF. Enzymes degrading bacterial chemotactic F-met peptides in human ileal and colonic mucosa. F Gastroenterol Hepatol 1990; 5: 375-81

4 Cole AT, Smith C, Kurlak L, Hawkey CJ. Reduced neutrophil neutral endopeptidase $24: 11$ in ulcerative colitis. In: Schölmerich J, Kruis W, Goebell H, Hohenburger D, Gross V, eds. Inflammatory bowel diseases - pathophysiolog as basis for treatment. Proceedings of Falk Symposium No 67. Regensburg: Kluwer Academic, 1993.

\section{Reply}

EDITOR, - The proposal by Cole and Hawkey for a role of enkephalinase (membrane metalloendopeptidase, EC 3.4.24.11) in the degradation of bacterial F-Met-Phe-Leu and other proinflammatory peptides in patients with ulcerative colitis seems an interesting suggestion. We feel, however, that this idea is not supported by their data' and, furthermore, seems unlikely.

Firstly, the assay they used to establish a slight significant change $(p=0 \cdot 048)$ in a small sample of patients $(n=6)$ is incorrect as thiorphan is used at a concentration 10000 times higher than actually required for a specific assay.' We have also found that this experimental condition leads to an overestimation of the specific enzyme activity of isolated human neutrophils by up to $50 \%$. Secondly, among the six patients studied by Cole et al, 'two were receiving steroids, three steroid enema, five oral salicylates, and four azathioprine' and it would seem, therefore, rather premature to attribute any change in their neutrophils to the disease rather than to such treatments. Thirdly, it seems misleading to study inactivation of pro-inflammatory F-Met peptides by peptidases of neutrophils rather than by intestinal mucosa. Indeed, proinflammatory F-Met peptides generated by intestinal bacteria may play a part in intestinal inflammatory disorders if they cross the epithelial barrier in which local peptidases seem to play a critical role. Hence Chadwick et al ${ }^{3}$ have identified the major mucosal peptidase responsible for F-Met-Leu-Phe hydrolysis as a carboxypeptidase which is down regulated in Crohn's disease and have also suggested a role for a F-Met deformylase and a peculiar F-Met aminopeptidase. By contrast, a role for enkephalinase, whose activity in mucosa is greater than in neutrophils, was not shown in this study.

In addition, it seems likely that bacterial colonisation and pullulation within the intestinal lumen facilitates the crossing of bacterial pro-inflammatory peptides. In this respect, the use of a purely antisecretory agent, such as the enkephalinase inhibitor acetorphan as an antidiarrhoeal agent seems preferable to traditional opiate like antidiarrhoeals, such as loperamide, with an antitransit mode of action. ${ }^{+5}$ In support of this idea, various opiates, given to patients with chronic ulcerative colitis to control debilitating diarrhoea, were found to induce, even after a few days and in a high percentage of subjects (17 of 18 in one study), a fulminating ulcerative colitis complicated by toxic megacolon." This effect is presumably a consequence of their action on colonic motility seen after a single small dose was given in 14 patients. Whereas, various enkephalinase inhibitors seem without the typical antitransit effects of $\mu$ opiate antidiarrhoeals, " both in rodents ${ }^{x}$ and humans."

The suggested role of enkephalinase in down regulating inflammatory response in airways, through degradation of tachykinins, "' has also been challenged recently as the inhibitor acetorphan given to volunteers with asthma had no deletorious effects. " Hence the antiinflammatory role of the peptidase is far from established.

$$
\begin{array}{r}
\text { J-C SCHWARTZ } \\
\text { Neurobiologv and Pharmacology Unit, } \\
\text { Institut National de la Santé et de la } \\
\text { Recherche Médicale Centre Paul Broca, } \\
75014 \text { Paris, France } \\
\text { P BAUMER } \\
\text { Department of Gastroenterologv, } \\
\text { Hopital Rothschild, } \\
75012 \text { Paris, France }
\end{array}
$$

1 Cole AT, Smith C, Kurlak I, Hawkey CJ Reduced neutrophil neutral endopeptidase 24.11 in ulcerative colitis. In: Proceedings of the interna tional symposium on pathophysiology and therapy in inflammatory bowel disease. Regensburg, Ger many, 1992

2 Roques BP, Fournié-Zaluski MC, Soroca E, Lecomte JM, Malfroy B, Llorens C, et al. Th enkephalinase inhibitor thiorphan shows ant nociceptive activity in mice. Nature $1980 ; 288$ : 286-8

3 Chadwick VS, Schlup MMI, Cooper BT, Broom MF. Enzymes degrading bacterial chemotactic
F-met peptides in human ileal and colonic mucosa. 7 Gastroenterol Hepatol 1990; 5: 375-81.

+ Kachel G, Ruppin H, Hagel J, Barina W Meinhardt M, Domschke W. Human intestinal motor activity and transport: effects of a synmotor activity and transport: effects of a synthetic opiate. Gastroenterology 1986; 90: 85-93. Schiller LR, Santa Ana CA, Morawski SG Fordtran JS. Mechanism of the antidiarrheal effect of loperamide. Gastroenterologv 1984; 86 $1475-80$

6 Smith FW, Law DH, Nickel WF Jr, Sleisenge $\mathrm{MH}$. Fulminant ulcerative colitis with toxi dilatation of the colon: medical and surgical management of eleven cases with observation regarding etiology. Gastroenterology 1962; 42 233-43.

7 Garrett JM, Sauer WG, Moertel CG. Colonic motility in ulcerative colitis after opiate adminismotility in ulcerative colitis after opiate adm
tration. Gastroenterolog $1967 ; 53: 93-100$.

8 Marcais-Collado H, Uchida G, Costentin J Schwartz JC, Lecomte JM. Naloxone-reversible antidiarrhoeal effects of enkephalinase inhibiantidiarrhoeal effects of enkephalinase

9 Bergmann JF, Chaussade S, Couturier D, Baumer Ph, Schwart\% JC, Lecomte JM. Effects of acetorphan, an antidiarrhoeal enkephalinase inhibitor, on orocaecal and colonic transit times in healthy volunteers. Aliment Pharmacol Ther 1992; 6: 305-13.

10 Nadel JA. Decreased neutral endopeptidases: possible role in inflammatory diseases of airways. Lung 1990; 168: 123-7.

11 Nichol GM, O'Connor BJ, Lecomte JM, Chung KF, Barnes PJ. Effect of neutral endopeptidase inhibitor on airway function and bronchial inhibitor on airway function and bronchial
responsiveness in asthmatic subjects. Eur 7 responsiveness in asthmatic

\section{NOTES}

National Association for Colitis and Crohn's Disease

NACC is pleased to invite applications for the 1993 grant awards. Projects may address any aspect of inflammatory bowel disease. NACC is particularly keen to encourage not only high quality mainstream research, but also welcomes applications which may be considered as realistic "what if research projects. These are likely to be smaller, relatively inexpensive applications which might be viewed less favourably by larger, less specialised organisations. Although all applications are assessed together, NACC wishes to encourage projects which address social and quality of life issues of inflammatory bowel disease where methodol ogy remains difficult.

The closing date for applications is Friday 30 April 1993. Further details are available from Dr P B McIntyre, Honorary Secretary, Medical Advisors NACC, Queen Elizabeth II Hospital, Howlands, Welwyn Garden City Herts AL7 4HQ

\section{Barcelona '93 - II United European Gastroenterology Week}

This will take place from 19 to 24 July 1993 in Barcelona, Spain. Further information from Prof J R Malagelada, c/o UNICONGRESS Calle Calvet 55-57 (4th floor), 08021 Barcelona, Spain (Tel: 3434140322 ; fax: 343 4140251 ). 